\title{
Pemungutan Suara Ulang pada Pemihan Umum Tahun 2019 di Indonesia
}

\section{Re-Voting in General Election 2019 in Indonesia}

\author{
Retno Sari Handayani* \\ Fakultas Ilmu Sosial dan Ilmu Politik, Universitas Andalas, Indonesia
}

Diterima: 22 Agustus 2019; Disetujui: 21 September 2019; Dipublish: 6 Januari 2020

\begin{abstract}
Abstrak
Sepertinya Indonesia belum juga menemukan metode yang tepat dalam mengaplikasikan demokrasi prosedural untuk memilih anggota legislatif dan eksekutif secara langsung. Setiap penyelenggaraan pemilu dari masa ke masa masih selalu menyisakan persoalan. Masalah yang hendak dibahas dan dianalisa pada penelitian ini adalah bagaimana penerapan Undang-Undang Nomor 7 Tahun 2017 Pasal 372 mengenai Pemungutan Suara Ulang (PSU) serta menganalisis problematika sosial yang muncul dalam pelaksanaanya. Metode penelitian yang digunakan pada penelitian ini adalah metode penelitian hukum secara normatif-empiris dengan kategori penelitian live case study dengan kategori penelitian yakni peristiwa hukum yang prosesnya sedang berlangsung. Adapun yang dijadikan sumber penelitian berupa ketentuan hukum normatif yakni Undang-Undang Nomor 7 Tahun 2017 Pasal 372 serta aturan teknis yang dibuat berkenaan dengan norma tersebut. Hasil analisis menunjukkan bahwa pelaksanaan peraturan yang dibuat mengakibatkan munculnya berbagai permasalahan sosial. PSU menimbulkan problematika baru bagi pemilih, penyelenggara pemilu, serta peserta pemilu. Muncul fenomena berupa angka partisipasi turun, potensi tekanan kecemasan dalam lingkup masyarakat karena perhatian yang berlebihan dari aparat maupun kandidat hingga adanya distorsi preferensi pilihan pada pelaksanaan PSU. Persoalan yang muncul tersebut kemudian diharapkan menjadi pertimbangan agar PSU yang dilaksanakan menjadi solusi yang paling tepat namun tetap secara optimal meminimalisir adanya permasalahan sosial dimasyarakat yang muncul. Kata Kunci: Pemungutan Suara Ulang, Undang-Undang, Pemilu, Peraturan
\end{abstract}

\begin{abstract}
It seems that Indonesia has not yet found the right method in implementing procedural democracy to elect legislative and executive members directly. Every election from time to time still always leaves problems. The problem to be discussed and analyzed in this study is how the application of Law Number 7 of 2017 Article 372 concerning Voting (PSU) and analyze the social problems that arise in its implementation. The research method used in this study is the normative-empirical legal research method with the live case study research category with the research category that is the legal events that the process is ongoing. As for the source of research in the form of normative legal provisions namely Law Number 7 of 2017 Article 372 as well as technical rules made with respect to these norms. The analysis shows that the implementation of the regulations made resulted in various social problems. PSU raises new problems for voters, election organizers, and election participants. A phenomenon in the form of decreased participation rates, the potential for anxiety pressure within the community because of excessive attention from officials and candidates to the distortion of preference preferences in the implementation of the PSU. The problems that arise are then expected to be considered so that the implemented PSU becomes the most appropriate solution but can still optimally minimize social problems in the community that may arise.
\end{abstract}

Keywords: Re Election, Law, Election, Regulation

How to Cite: Handayani, R.S. (2019). Pemungutan Suara Ulang pada Pemilihan Umum Tahun 2019 di Indonesia. PERSPEKTIF, 9 (1): 9-18

\footnotetext{
*Corresponding author:

E-mail: aku.retno440@gmail.com
}

ISSN 2085-0328 (Print)

ISSN 2684-9305(Online) 


\section{PENDAHULUAN}

Berbicara mengenai demokrasi dalam suatu negara akan selalu berakhir pada pembahasan mengenai bagaimana proses pemilihan perwakilan rakyat di legislatif dan eksekutif. Proses pemilihan ini merujuk pada penyelenggaraan pemilu yang dijalankan serta cara mengimplementasikan asas-asas yang diakui secara internasional. Asas-asas penyelenggaraan pemilu yang demokratis di indonesia sering disebut sebagai luber jurdil, yakni langsung, umum, bebas, rahasia, jujur dan adil. Momentum Reformasi selalu dianggap sebagai titik awal penerapan secara substansial asasasas tersebut. Di sisi lain, untuk menerapkan asas-asas tersebut sepertinya Indonesia belum juga menemukan metode yang tepat dimana terlihat pada persoalanpersoalan yang muncul pada tiap penyelenggaraan pemilu dari masa kemasa.

Menjaga demokrasi tetap berjalan dalam sebuah negara nyatanya memang harus diimplementasikan melalui pemilu. Banyak pemerhati menyampaikan pentingnya pemilu dalam sebuah negara yang mendeklarasikan diri sebagai negara demokrasi. Pertama, Pemilu merupakan tolok ukur demokrasi. Melalui Pemilu, pemerintahan memiliki mandat dan kewajiban yang harus dijalankan sebagai pejabat resmi. Dalam Pemilu suara rakyat menentukan kebijakan dalam pemerintahan dan melanjutkan keberlangsungan pembangunan secara demokratis (Helgesen, 2013). Kedua, Pemilu adalah puncak dari partisipasi politik paripurna warga negara yang diorganisasikan di sebuah negara (Wall, 2006).

$\mathrm{Di} \quad$ Indonesia

penyelenggaraan pemilu semenjak penggulingan Soeharto telah dilaksanakan lima kali, yakni tahun 1999, 2004, 2009, 2014, 2019. Periode pemilu tersebut juga menelurkan perundang-undangan yang baru, seperti latah bagi para penyelenggara negara untuk membuat aturan baru jika periode pemilu tiba, dan aturan tersebut bagi berbagai kalangan merupakan norma yang diujicobakan, jika gagal akan dievaluasi pada penyelenggaraan pemilu selanjutnya sehingga munculah undang-undang baru tentang penyelenggaraan pemilu. Penyelenggaraan pemilu 1999 berdasarkan Undang-Undang Nomor 3 Tahun 1999 sebagai cikal bakal pemilu yang jujur dan adil dimana pada masa sebelum reformasi tidak ditemui.

Pemilu 2004 adalah pemilu yang menempatkan rakyat untuk memilih langsung wakil mereka untuk mendapatkan kursi di DPR, DPD, dan DPRD serta memilih langsung presiden dan wakil presiden. Berdasarkan pada Undang-Undang Nomor 12 Tahun 2003 Pemilu 2004 diselenggarakan secara serentak pada tanggal 5 April 2004 untuk memilih 550 Anggota DPR, 128 Anggota DPD, serta Anggota DPRD (DPRD Provinsi maupun DPRD Kabupaten/Kota). Sedangkan untuk memilih presiden dan wakil presiden menggunakan dasar Undang-Undang Nomor 23 Tahun 2003. Beberapa norma perundang-undangan dalam penyelenggaraan pemilu tersebut merupakan gambaran bahwa penyelenggaraan pemilu sebelumnya belum memenuhi harapan penyelenggaraan pemilu baik itu dalam hal prosesnya maupun nilai-nilai prinsipil, oleh sebab itu dibuat peraturan perundang-undangan baru dalam rangka penyempurnaannya demi peralihan kekuasaan yang berlangsung damai serta melegitimasi kedaulatan rakyat, yang dalam hal ini dilaksanakan oleh warga yang telah memenuhi syarat tertentu yang kemudian disebut sebagai Pemilih.

Undang-Undang Nomor 7 Tahun 2017 yang diundangkan pada tanggal 16 Agustus 2017 merupakan dasar penyelenggaraan pemilu tahun 2019 dimana pemilih dihadapkan untuk memilih calon anggota DPRD 
kabupaten/kota, DPRD Provinsi, DPD, DPR RI serta Presiden dan Wakil Presiden dalam waktu yang bersamaan yakni 17 April 2019. Atas dasar tersebut, beberapa norma yang diatur menimbulkan efek teknis penyelenggaraan diantaranya jumlah Tempat Pemungutan Suara (TPS) yang membengkak hingga 813.350 jumlahnya karena jumlah pemilih yang dikurangi setiap TPS yang sebelumnya mencapai 500 orang tiap TPS menjadi 300 orang. Dasar pengurangan tersebut secara teknis adalah untuk menyesuaikan waktu yang dibutuhkan pemilih dalam memberikan suara serta petugas Kelompok Petugas Pemungutan Suara untuk melakukan penghitungan suara (Hasibuan, Kadir \& Nasution (2018).

Efek lanjutan dari membengkaknya jumlah TPS adalah kebutuhan akan personel pengamanan, pengamanan hingga petugas KPPS itu sendiri, sementara penyelenggaraan pemilu tahun 2019 ini merupakan pola baru yang selama periode pemilu 2004 hingga 2014 relatif berbeda. Potensi atas terjadinya pemungutan suara ulang akibat tidak pahamnya aturan norma dan teknis pemungutan suara di TPS menjadi semakin besar, ditambah lagi kepentingan politik peserta pemilu menambah kerawanan penyelenggaraan pemilu karena pemilih pada pemilu 2019 terbelah pada dua pasangan calon presiden dan wakil presiden.

Kerangka hukum yang kuat merupakan bagian penting dari proses penyelenggaraan pemilu. Kerangka hukum ini, harusnya memenuhi asas-asas penyelenggaraan pemilu yang baik, yang akan mencerminkan nilai demokrasi yang menjadi tujuan akhir proses itu sendiri. Dalam Pasal22E ayat (1) Undang-Undang Dasar Negara Republik Indonesia Tahun 1945 dinyatakan, pemilihan umum dilaksanakan secara langsung, umum, bebas, rahasia, jujur dan adil setiap lima tahun sekali. Sesuai ketentuan tersebut, "adil" merupakan salah satu asas penyelenggaraan pemilu. Oleh karena itu, asas tersebut haruslah menjiwai sistem pemilu yang terdiri dari hukum pemilu (electoral law) maupun proses penyelenggaraan pemilu (electoral process) (Fahmi, 2016). Dalam konteks hukum pemilu, tanpa hukum pemilu yang adil, sulit tentunya menghasilkan pemilu yang dipercaya. Rumusan masalah yang hendak dibahas dan dianalisa pada penelitian ini adalah bagaimana penerapan Undang-Undang Nomor 7 Tahun 2017 Pasal 372 mengenai Pemungutan Suara Ulang serta menganalisis problematika sosial yang muncul dalam penerapannya.

Selain kerangka hukum yang kuat, penyelenggaraan pemilu yang diharapkan tentulah mengharapkan tingginya partisipasi pemilih untuk bersedia datang ke Tempat Pemungutan Suara secara sukarela (Zega, Muda, Batubara \& Suharyanto (2018); Wardhani (2018). Partisipasi politik menjadi bagian penting dalam nyawa politik sebuah negara, utamanya bagi negara yang mendeklarasikan dirinya sebagai negara demokrasi, partisipasi politik menjadi salah satu indikator penting (Suharyanto, 2014). Menurut Sitepu (2012) partisipasi politik adalah suatu kegiatan dari warga negara baik secara langsung maupun tidak langsung yang berkaitan dengan kebijakan-kebijakan pemerintah, baik itu dilakukan oleh orang per orang secara parsial maupun kelompok secara spontan maupun secara dimobilisasi. Lebih dari itu, partisipasi politik dapat dijelaskan sebagai kegiatan yang dilakukan warga negara untuk terlibat dalam proses pengambilan keputusan yang dilakukan pemerintah. (Kusmanto, 2013). Partisipasi politik masyarakat erat kaitannya dengan hak dan kewajiban personal secara individu atau kelompok sebagai warga negara dalam hal menggunakan segala sumber daya sosialnya untuk mempengaruhi proses pengambilan keputusan dalam pemerintah (Susi \& Adelita, 2015). 
Menurut Kartini (2018), pengalaman penyelenggaraan pilkada serentak tahun 2015 dan 2017, Bawaslu sebagai pengawas penyelenggaraan pemilu belum memiliki data mengenai pelanggaraan pemilu seperti halnya dengan KPU. Setidaknya harus ada kajian yang diberbagai TPS mengenai perilaku pemilih terutama mengenai partisipasi dan kencenderungan partisipasinya jika diadakan PSU. Kemudian dari kajian tersebut diharapkan juga muncul persentase jumlah pemilih yang melakukan kesalahan yang menjadi penyebab PSU dibandingkan jumlah pemilih. Dari presentase tersebut kemudian diharapkan muncul angka perbandingan yang bisa digunakan sebagai dasar pertimbangan penyusunan aturan selanjutnya bagaimana pesyaratan teknis yang tepat jika PSU harus dilaksanakan.

\section{METODE PENELITIAN}

Metode penelitian yang digunakan pada penelitian ini adalah metode penelitian normatif-empiris dengan kategori penelitian live case study. Kategori penelitian ini menganalisa peristiwa hukum yang prosesnya masih berlangsung. Adapun yang dijadikan sumber penelitian berupa ketentuan hukum normatif yakni Undang-Undang Nomor 7 Tahun 2017 Pasal 372 serta aturan teknis yang dibuat berkenaan dengan norma tersebut yang dibuat oleh penyelenggara pemilu, yakni Komisi Pemilihan Umum.

Penelitian ini bertujuan untuk mengkaji tentang implementasi aturan yang dibuat oleh Bawaslu dan Komisi Pemilihan Umum sebagai penyelenggara pemilu yang melekat, dan berbagai problematika sosial yang muncul baik dari segi pemilih, pihak peserta pemilu maupun kandidat calon legislatif atau calon DPD. Pada level normatif akan digunakan pendekatan studi kepustakaan dengan sumber data yang digunakan dalam penelitian ini adalah buku-buku, peraturan perundangundangan, dokumen-dokumen, press realease berbagai lembaga yang berkepentingan melalui media massa baik cetak maupun online dan tulisan-tulisan lainnya yang berkaitan dengan permasalahan yang sedang diteliti, dengan metode pengolahan data adalah dengan menggunakan metode kualitatif dan analisis data bersifat deduktif.

\section{HASIL DAN PEMBAHASAN}

Munculnya Undang-Undang Nomor 7 Tahun 2017 merupakan perwujudan sistem ketatanegaraan yang demokratis dan beritegritas untuk menjamin adanya konsistensi dan kepastian hukum serta pemilihan umum yang efektif dan efisien. Selain itu, pemilu merupakan sarana perwujudan kedaulatan rakyat untuk menghasilkan wakil rakyat dan pemerintahan negara yang berlandaskan Pancasila serta Undang-Undang Dasar Negara Republik Indonesia Tahun 1945 sebagaimana cita-cita dan tujuan nasional yang termaktub dalam Pembukaan Undang-Undang Dasar Negara Republik Indonesia Tahun 1945.

Penyelenggaraan pemilu haruslah menjamin tersampaikannya aspirasi rakyat secara langsung, umum, bebas, rahasia, jujur, dan adil. Dengan pertimbangan kesederhanaan dan penyatuan penyelenggaraan pemilu, maka Undang-Undang Nomor 7 Tahun 2017 mengatur bahwa Pemilu diselenggarakan untuk memilih anggota Dewan Perwakilan Rakyat, Dewan Perwakilan Daerah, Presiden dan Wakil Presiden, dan untuk memilih anggota Dewan Perwakilan Rakyat Daerah dalam satu waktu yang bersamaan.

Proses penyelenggaraan pemilu tahun 2019 dimulai semenjak undangundang ini disahkan, dimana penyelenggara pemilu yang diberi kewenangan dalam menyelenggarakan pemilu terdiri atas Komisi Pemilihan Umum, Pengawas Pemilu, dan Dewan 
Kehormatan Penyelenggara Pemilu yang merupakan satu kesatuan fungsi.

Undang-Undang Nomor 7 Tahun 2017 terdiri atas 573 pasal yang mengatur secara komprehensif mengenai penyelenggaraan pemilu, termasuk dalam Bab IX undang-undang tersebut yang mengatur mengenai Pemungutan Suara Ulang, Penghitungan Suara Ulang dan Rekapitulasi Ulang. Ketentuan yuridis mengenai pemungutan suara ulang berbunyi sebagai berikut :

Pasal 372

(1) Pemungutan suara di di TPS dapat diulang apabila terjadi bencana alam dan/atau kerusuhan yang mengakibatkan hasil pemungutan suara tidak dapat digunakan atau penghitungan suara tidak dapat dilakukan.

(2) Pemungutan suara di TPS wajib diulang apabila dari hasil penelitian dan pemeriksaan Pengawas TPS terbukti terdapat keadaan sebagai berikut :

a. Pembukaan kotak suara dan/atau berkas pemungutan suara tidak dilakukan menurut tata cara yang ditetapkan dalam ketentuan peraturan perundang-undangan;

b. Petugas KPPS meminta Pemilih memberikan tanda khusus, menandatangani, atau menuliskan nama atau alamat pada suaray suara yang sudah digunakan;

c. Petugas KPPS merusak lebih dari satu surat suara yang sudah digunakan oleh Pemilih sehingga surat suara tersebut menjadi tidak sah; dan/atau

d. Pemilih yang tidak memiliki kartu tanda penduduk elektronik dan tidak terdaftar di daftar pemilih tetap dan daftar pemilih tambahan.

Pasal 373

(1) Pemungutan suara ulang diusulkan oleh KPPS dengan menyebutkan keadaan yang menyebabkan diadakannya pemungutan suara ulang,
(2) Usul KPPS diteruskan kepada PPK dan selanjutnya diajukan kepada KPU Kabupaten/Kota untuk pengambilan keputusan diadakannya pemungutan suara ulang

(3) Pemungutan suara ulang paling lama 10 (sepuluh) hari setelah hari pemungutan suara berdasarkan keputusan KPU Kabupaten/Kota

(4) Pemungutan suara ulang sebagaimana dimaksud pada ayat (1) hanya dilakukan untuk 1 (satu) kali pemungutan suara ulang.

Jika dibandingkan dengan UndangUndang Nomor 8 Tahun 2014 yang mengatur penyelenggaraarn pemilu tahun 2014, pengaturan mengenai pemungutan suara ulang diatur didalam Pasal 221 dan 222 Undang-Undang Nomor 8 Tahun 2012 yang berbunyi sebagai berikut :

Pasal 221

(1) Pemungutan suara di TPS dapat diulang apabila terjadi bencana alam dan/atau kerusuhan yang mengakibatkan hasil pemungutan suara tidak dapat digunakan atau penghitungan suara tidak dapat dilakukan.

(2) Pemungutan suara di TPS wajib diulang apabila dari hasil penelitian dan pemeriksaan Pengawas Pemilu Lapangan terbukti terdapat keadaan sebagai berikut:

a. Pembukaan kotak suara dan/atau berkas pemungutan dan penghitungan suara tidak dilakukan menurut tata cara yang ditetapkan dalam ketentuan peraturan perundang-undangan;

b. Petugas KPPS meminta Pemilih memberikan tanda khusus, menandatangan, atau menuliskan nama atau alamat pada surat suara yang sudah digunakan; dan/atau

c. Petugas KPPS merusak lebih dari satu surat suara yang sudah digunakan oleh Pemilih sehingga 
surat suara tersebut menjadi tidak sah

Berdasarkan norma tersebut Komisi Pemilihan Umum sebagai penyelenggara pemilu membuat aturan teknis pemungutan suara yakni Peraturan KPU Nomor 9 Tahun 2019 tentang Perubahan atas Peraturan Komisi Pemilihan Umum Nomor 3 Tahun 2019 tentang Pemungutan dan Penghitungan Suara Dalam Pemilihan Umum, dimana pasal yang menjelaskan mengenai Pemungutan Suara Ulang yang berbunyi :

\section{Pasal 65}

(1) Pemungutan suara di TPS dapat diulang apabila terjadi bencana alam dan/atau kerusuhan yang mengakibatkan hasil Pemungutan Suara tidak dapat digunakan atau Penghitungan Suara tidak dapat dilakukan.

(2) Pemungutan Suara di TPS wajib diulang apabila dari hasil penelitian dan pemeriksaan Pengawas TPS terbukti terdapat keadaan sebagai berikut:

a. pembukaan kotak suara dan/atau berkas Pemungutan dan Penghitungan Suara tidak dilakukan menurut tata cara yang ditetapkan dalam ketentuan peraturan perundang-undangan;

b. petugas KPPS meminta Pemilih memberikan tanda khusus, menandatangani, atau menuliskan nama atau, alamat pada surat suara yang sudah digunakan;

c. petugas KPPS merusak lebih dari satu surat suara yang sudah digunakan oleh Pemilih sehingga surat suara tersebut menjadi tidak sah; dan/atau

d. Pemilih yang tidak memiliki KTP-el dan tidak terdaftar di DPT dan DPTb memberikan suara di TPS.

\section{Pasal 66}

(1) Pemungutan Suara ulang diusulkan oleh KPPS dengan menyebutkan keadaan yang menyebabkan diadakannya Pemungutan Suara ulang. (2) Usul KPPS diteruskan kepada PPK dan selanjutnya diajukan kepada KPU/KIP Kabupaten/Kota untuk pengambilan keputusan.

Berdasarkan Peraturan KPU tersebut, secara teknis ada poin utama yang berbeda dengan norma perundang-undangan. Bahwa ada ketentuan bagaimana pemungutan suara harus diulang adalah jika ada orang yang tidak memiliki KTP elektronik atau tidak terdaftar sebagai pemilih dalam DPT atau DPTb memberikan suara di TPS.

Satu mekanisme yang diterapkan dalam pemilu tahun 2019 adalah kewajiban setiap pemilih untuk memiliki KTP-el. KTP-el menjadi identitas wajib bagi pemilih sebagai dasar persyaratan wajib masuk sebagai pemilih selain persyaratan lain sebagaimana diatur dalam Undang-Undang Nomor 7 Tahun 2017 Pasal 348.

Pada pemilu 2019, setidaknya 2.767 Tempat Pemungutan Suara harus melaksanakan Pemungutan Suara Lanjutan, Pemungutan Suara Susulan, hingga Pemungutan Suara Ulang sebagaimana rilis resmi pada website resmi Komisi Pemilihan Umum. Diantara 2.767 TPS tersebut, penyelenggaraan Pemungutan Suara Ulang terjadi diakibatkan oleh beberapa hal,seperti ketidakpahaman KPPS, tekanan dari Pengawas Lapangan hingga tekanan dari pemilih itu sendiri.

Pada pertemuan pemerhati demokrasi prosedural di Indonesia yang diselenggarakan oleh Bawaslu dalam rangka evaluasi Pemilu Tahun 2019, problematika PSU yang digelar merupakan imbas dari manajemen teknis pemilu yang masih lemah. Sebelum membicarakan mengenai manajemen teknis, tentu ditilik kembali bagaimana aturan mengenai pemilu ini dibuat hingga disahkan. Undang-Undang Nomor 7 Tahun 2017 disahkan pada 16 Agustus 2017. Jika 
ditarik ke pelaksanaannya, hari pemungutan suara adalah 17 April 2019, jarak antara disahkan undang undang tersebut hingga hari pemungutan suara adalah 20 bulan 1 hari. Sementara pada undang-undang tersebut menyebutkan bahwa tahapan penyelenggaraan pemilu paling lambat 20 bulan saja sebelum hari pemungutan suara. Jeda antara disahkannya undang-undang dengan tahapan dimulai adalah 1 hari saja, dari hal tersebut membawa dampak kesiapan penyelenggara yang diburu waktu untuk menyiapkan pedoman teknis mengenai penyelenggaraan pemilu yang tidak sedikit.

Dalam perkembangannya, UndangUndang Nomor 7 Tahun 2017 ini dihujani dengan berbagai gugatan ke Mahkamah Konstitusi oleh berbagai pihak yang merasa dirugikan dengan diberlakukannya undang undang tersebut. Putusan Mahkamah Konstitusi yang menganulir beberapa pasal mengakibatkan penyelenggara pemilu untuk menyesuaikan aturan teknis yang sudah dibuat dan dijadikan pedoman bagi penyelenggara ditingkatan bawahnya.

Mengamati mengenai PSU yang diselenggarakan diberbagai wilayah di Indonesia juga dapat dikategorikan faktorfaktor yang mengakibatkannya. Lemahnya manajemen teknis penyelenggaraan merujuk kepada adanya faktor lain yang mendasarinya, kesiapan penyelenggara yang dipaksakan untuk menyiapkan aturan teknis yang komprehensif namun dalam jarak waktu yang lumayan singkat.

Bahkan pada kurun waktu yang cukup berdekatan dengan hari pemungutan suara, ada putusan Mahkamah Konstitusi Nomor 20/PUUXVII/2019 tanggal 28 Maret 2019 yang mengakibatkan perubahan teknis yang cukup signifikan mengenai pemilih yang pindah memilih karena beberapa faktor.

Putusan Mahkamah Konstitusi tersebut merupakan contoh rintanganrintangan yang harus dihadapi KPU, terutama mendekati hari pemungutan suara, karena penyelenggaraan pemilu pada masa-masa mendekati hari pemungutan suara tertumpu pada penyelenggara ad hoc yakni Panitia Pemilihan Kecamatan (PPK) sebagai penyelenggara tingkat kecamatan, Panitia Pemungutan Suara (PPS) sebagai penyelenggara tingkat Desa/Kelurahan atau sebutan lainnya yang setingkat hingga Kelompok Penyelenggara Pemungutan Suara yang merupakan penyelenggara pemilu tingkat TPS.

KPPS yang direkrut oleh KPU berjumlah tujuh personel dan sudah harus terbentuk paling lambat satu bulan sebelum hari pemungutan suara. Sekalipun KPPS terpilih harus melalui seleksi dan lulus persyaratan tertentu yang tertuang dalam Peraturan KPU Nomor 3 Tahun 2018, latar belakang yang beragam akan ditemui yang turut mempengaruhi dalam kecakapan memahami tugas dan fungsinya sebagai KPPS.

Sebagai petugas penyelenggara pemungutan suara garda terdepan disetiap TPS, KPPS dihadapkan kepada pemilih yang memiliki karakter yang beragam, petugas pengawas, hingga saksi, maka dari itu selain cakap secara teknis, KPPS harus memiliki modal independensi yang kuat serta mampu menghadapi tekanantekanan yang memiliki kepentingan, belum lagi kendala fisik karena beban tugas yang berat semenjak persiapan lokasi TPS hingga siap digunakan sebagaimana temuan Bawaslu pada penyelenggaraan PSU di TPS 163 Kelurahan Pulau Gebang, Kecamatan Cakung, Jakarta Timur dimana terjadi kesalahan penandatanganan Surat Suara yang seharusnya kewajiban Ketua KPPS, namun dilakukan oleh pemilih sehingga PSU wajib diselenggarakan.

Berbagai faktor yang mempengaruhi proses tahapan pemilu tersebut tentu akan ditanggulangi oleh setiap pihak yang berwenang agar proses pemilu tetap berjalan sesuai dengan apa saja yang telah dijadwalkan. Membicarakan manajemen 
teknis yang baik, bukan saja mengenai pelaksanaannya, namum seluruh proses manajemen itu sendiri yakni mulai dari perencanaan, pengorganisasian, pelaksanaan hingga evaluasi keseluruhan proses yang sudah dijalankan.

Jika dirangkum, pada manajemen teknis, kendala yang dihadapi penyelenggara diantaranya adalah (a) sempitnya waktu yang disediakan untuk merencanakan program kegiatan yang terdiri atas berbagai aspek, yakni penyusunan anggaran, penyusunan aturan teknis hingga jadwal tahapan itu sendiri; (b) seringnya ada putusan atas gugatan ke Mahkamah Konstitusi ataupun Mahkamah Agung yang mempengaruhi proses yang sedang berlangsung, sehingga roda tahapan menjadi tumpang tindih, atau kembali mundur ke belakang. Sebagai contoh mengenai jumlah komisioner KPU Kabupaten/Kota dan PPK, sehingga penyelenggara setingkat diatasnya harus melalui proses rekrutmen ulang yang tentu menyita waktu dan perhatian.; (c) fungsi pelatihan teknis yang tidak dioptimalkan. Kecakapan KPPS penting selain kesiapan fisik dan mental saja, bimbingan teknis yang diselenggarakan KPU masih sering diabaikan sebagaian penyelenggara terutama yang sudah berpengalaman menjadi petugas KPPS sebelumnya. Lemahnya pemahaman teknis ini menimbulkan potensi mudahnya KPPS menerima rekomendasi berbagai pihak yang belum tentu dibenarkan dalam aturan.

Faktor pada KPPS yang tak memahami aturan ataupun paham namun tidak memiliki kuasa melawan tekanan dilapangan tersebutlah yang menyebabkan berbagai TPS harus menyelenggarakan PSU. Penyelenggaraan PSU ini pada akhirnya akan memunculkan persoalanpersoalan baru yang mau tak mau akan menodai integritas pemilu yang langsung, umum, bebas, rahasia, jujur dan adil.

Pertama, kesiapan pemilih. Bagi pemilih yang telah memberikan suara pada hari pemungutan suara tentu mengharap bahwa hasil pemilu yang sudah diikuti merupakan gambaran bagaimana negara memberikan kesempatan yang sama bagi pemilih yang sudah memenuhi syarat. Sementara pemungutan suara ulang bagi pemilih sebelumnya yang telah memenuhi syarat dan memberikan suara merupakan 'beban' baru, karena pemungutan suara ulang mengarahkan pemilih untuk mengulang kembali pemungutan suara yang sudah diikuti. Permasalahan tersebut cenderung menimbulkan sikap apatis pemilih, terlihat dalam beberapa pemungutan suara ulang tingkat partisipasi pemilih menurun, apalagi jika pemungutan suara ulang dilaksanakan pada hari kerja akan menimbulkan problematika teknis terutama bagi pemilih yang memiliki ikatan kerja.

Kedua, bagi peserta pemilu Pemungutan Suara Ulang telah menodai integritas pemilu itu sendiri. Pemilih telah ternodai dengan informasi-informasi mengenai hasil pemilu ditempat lain, sehingga preferensi pilihan dalam pemungutan suara ulang terdistorsi. Pemilih akan berpeluang untuk bertindak tak sama pada Pemungutan Suara Ulang karena berbagai pertimbangan subjektif pemilih. Belum lagi akan ada 'kesempatan' bagi kandidat untuk mendekati pemilih baik secara persuasif untuk memilihnya ataupun secara intimidatif dengan berbagai ancaman.

Ketiga, pemungutan suara ulang merupakan rekomendasi penyelenggara pemilu. Bisa dikatakan bahwa pemungutan suara ulang merupakan tindak lanjut dari kesalahan prosedur oleh penyelenggara itu sendiri, sementara efek yang terjadi bukan hanya pada pemilih namun juga pada kandidat peserta pemilu baik itu Partai Politik, DPD ataupun Presiden dan Wakil Presiden.

Keempat, dampak psikologis pemilih pada pemungutan suara ulang. Pada pemungutan suara ulang, bukan saja 
melibatkan KPPS sebagai petugas, namun aparat kepolisian dan TNI akan memberikan perhatian khusus dalam prosesnya. Keberadaan aparat ini akan menimbulkan dampak psikologis pemilih sehingga menimbulkan perasaan cemas dan berefek pula pada cara-cara pemilih memberikan suaranya.

Problematika sosial yang muncul karena adanya PSU disuatu TPS pada Pemilu Tahun 2019 sebenarnya dapat diantisipasi jika pertimbangan diadakannya PSU lebih jelas dan faktor jumlah kesalahan didalam pelaksanaan pemungutan suara sebelumnya dapat dikategorikan signifikan. Kelemahan pada butir b dan d Pasal 65 Peraturan KPU tidak menunjukkan adanya jumlah tertentu sebagai pertimbangan rujukan diadakannya PSU. Dengan kata lain jika pelanggaran KPPS pada poin tersebut terjadi pada satu pemilih saja maka otomatis sebagai penegakan peraturan, PSU wajib untuk dilaksanakan. Dalam prakteknya memang ditemukan banyak wilayah yang menyelenggarakan PSU karena faktor kesalahan pemilih yang tidak berhak memberikan suara namun tetap dilayani, dan jumlah pemilih tersebut tidaklah banyak, bahkan hanya kesalahan prosedur pada satu orang pemilih saja.

Jika dibandingkan dengan peraturan mengenai penyelenggaraan pilkada tahun 2018 , ada aturan yang mengatur mengenai jumlah minimal kesalahan untuk dilaksanakan PSU bisa dilihat pada peraturan KPU Nomor 8 Tahun 2018 pasal 59. Ada jumlah minimal lebih dari 1 pemilih memberikan suara namun sebenarnya tidak berhak memberikan suara disuatu TPS. Jika demikian maka bisa diasumsikan minimal ada 2 kesalahan pemilih akan membawa sejumlah banyak pemilih yang berhak dan sudah memberikan suara untuk memberikan suara ulang.

Menakar aturan tersebut serta problematika yang muncul kemudian pada penyelenggaraan PSU, dibutuhkan pertimbangan perhitungan signifikansi yang tepat antara jumlah pemilih yang melakukan kesalahan dibandingkan dengan jumlah pemilih terdaftar dan hadir di TPS dengan potensi penurunan jumlah pemilih yang bersedia memberikan suara kembali jika diwajibkan adanya penyelenggaraan PSU. Pertimbangan ini penting mengingat prinsip keadilan yang harus dipegang pada penyelenggaraan pemilu. Keadilan dalam hal ini adalah kesamaan kesempatan yang diberikan kepada pemilih dalam memberikan suara, karena PSU diselenggarakan pasca jadwal pemungutan serentak, tentu pertimbangan teknis pemilih harus juga diindahan, terutama jika pemilih memiliki kontrak kerja yang menimbulkan dilema bagi pemilih, sekalipun mengenai PSU sudah ada aturan mengenai hari pelaksanaanya dapat diliburkan.

\section{SIMPULAN}

Penyelenggaraan PSU merupakan bagian dari pemilu itu sendiri yang memang harus dipersiapkan, berbagai persyaratan tertentu sudah diatur mengenai penyebab hingga akhirnya PSU harus dilaksanakan. Sekalipun menjadi solusi atas permasalahan atas pemungutan suara yang tidak sesuai aturan yang ada, pemungutan suara ulang justru menimbulkan efek baru. Sekalipun dukungan masyarakat terhadap penyelenggaraan pemilu masih cukup tinggi (Widianingsih, 2017), pada prinsipnya pemungutan suara ulang merupakan efek dari kesalahan prosedur yang terjadi sebelumnya, harus dipertimbangkan signifikansi kesalahan prosedur yang sudah terjadi, terutama pada poin d pasal 65 Peraturan KPU Nomor 9 Tahun 2019 tentang Perubahan Peraturan KPU Nomor 3 Tahun 2019 tentang Pemungutan dan Penghitungan Suara dalam Pemilihan Umum.

Dalam poin $d$ tersebut tidak dijelaskan ketentuan jumlah pemilih yang mengakibatkan harus diselenggarakannya 
PSU. Dengan demikian dapat disimpulkan bahwa satu orang saja telah memberikan suara, namun dalam peraturan perundangundangan dan peraturan teknis tidak berhak, maka Pemungutan Suara Ulang tetap harus dilaksanakan. Jika Pemungutan Suara Ulang tidak dilaksanakan, maka KPPS dapat dikenakan tuntutan pidana sebagaimana Pasal 501 Undang-Undang Nomor 7 Tahun 2017 yang berbunyi 'Setiap anggota KPPS yang dengan sengaja tidak melaksanakan keputusan KPU Kabupaten/Kota untuk pemungutan suara ulang di TPS dipidana dengan pidana kurungan paling lama 1 (satu) tahun dan denda paling banyak Rp12.000.000,00 (dua belas juta rupiah). Melihat aturan ini sudah jelas bahwa PSU bagi beberapa kasus merupakan solusi akhir yang wajib dikerjakan, apapun dasar kesalahan yang sudah dilakukan. Problematika PSU yang terjadi sebagaimana diurai diatas menyisakan ruang diskusi lebih luas untuk mengevaluasi peraturan hukum yang melandasi serta solusi-solusi lain yang lebih tepat.

\section{DAFTAR PUSTAKA}

Alan Wall et all. (2006). Electoral Management Design: The International IDEA Handbook. IDEA. : Stockholm.

Fahmi, K. (2016). Menelusuri Konsep Keadilan Pemilihan Umum Menurut UUD 1945. Jurnal Cita Hukum, 4 (2):167-86.

Hasibuan, S.J. Kadir, A. \& Nasution, M.H.T. (2018). Strategi Komisi Pemilihan Umum Provinsi Sumatera Utara Dalam Meningkatkan Partisipasi Masyarakat Pada Pemilihan Gubernur Sumatera Utara 2018. PERSPEKTIF, 7 (1): 1-5.
Helgesen, Vigar. (2013) Electoral Process. IDEA : Stockholm.

https://bawaslu.go.id/

Ibrahim, J. (2006), Teori dan Metodologi Penelitian Hukum Normatif. Banyu Media Publishing: Malang

Kartini, D.S. (2018) Demokrasi dan Pengawas Pemilu. Journal of Governance.2 (2):146-62.

Kusmanto, H. (2013). Peran Badan Permusyawaratan Daerah dalam Meningkatkan Partisipasi Politik Masyarakat, JPPUMA: Jurnal Ilmu Pemerintahan dan Sosial Politik UMA, 1 (1): 41-47.

Sitepu, P.A.. (2012). Teori-Teori Politik. Yogyakarta: Graha Ilmu.

Sugiyono. (2010). Metode Penelitian Kuantitatif Kualitatif dan $R \& D^{\prime \prime}$. Bandung: Alfabeta.

Suharyanto, A., (2014). Partisipasi Politik Masyarakat Tionghoa dalam Pemilihan Kepala Daerah, JPPUMA: Jurnal Ilmu Pemerintahan dan Sosial Politik UMA, 2 (2): 166-175.

Susi, S. \& Lubis, A, (2015). Partisipasi Politik Perempuan pada Partai Keadilan Sejahtera Kota Medan, JPPUMA: Jurnal Ilmu Pemerintahan dan Sosial Politik UMA, 3 (1): 1-3.

Undang-Undang Nomor 7 Tahun 2017. UndangUndang Nomor 8 Tahun 2012. Peraturan KPU Nomor 9 Tahun 2019. https://kpu.go.id/

Wardhani, P.S.N. (2018). Partisipasi Politik Pemilih Pemula dalam Pemilihan Umum. JUPIIS: Jurnal Pendidikan Ilmu-Ilmu Sosial, 10 (1): 57-62.

Widianingsih Y. (2017) Demokrasi Dan Pemilu Di Indonesia: Suatu Tinjauan Dari Aspek Sejarah Dan Sosiologi Politik. Jurnal Signal, 5 (2):1-19.

Zega, M.A. Muda, I. Batubara, B.M. \& Suharyanto, A. (2018). Pengaruh Program Rumah Pintar Pemilu Terhadap Partisipasi Politik Masyarakat Pada Kantor Komisi Pemilihan Umum Kota Medan, PERSPEKTIF, 7 (2): 6065. 